\title{
Calibration and Simulation of the CERES-Sorghum and CERES-Maize Models for Crops in the Central-West Region of Paraná State
}

\author{
Paulo Vinicius Demeneck Vieira ${ }^{1}$, Paulo Sérgio Lourenço de Freitas ${ }^{1}$, Roberto Rezende ${ }^{1}$, Rivanildo Dallacort ${ }^{2}$, \\ João Danilo Barbieri ${ }^{1} \&$ Diego Fernando Daniel ${ }^{2}$ \\ ${ }^{1}$ State University of Maringá, Maringá, Paraná, Brazil \\ ${ }^{2}$ State University of Mato Grosso, Tangará da Serra, Mato Grosso, Brazil \\ Correspondence: João Danilo Barbieri, State University of Maringá, Maringá, Paraná, Brazil. E-mail: \\ jd.barbieri@hotmail.com
}

Received: August 29, 2019

Accepted: October 2, $2019 \quad$ Online Published: November 15, 2019

doi:10.5539/jas.v11n18p140

URL: https://doi.org/10.5539/jas.v11n18p140

\begin{abstract}
Simulation models have been widely used to generate yield data by forecasting climate variables and changes in growing seasons. The aim of this study was to calibrate genetic coefficients and simulate growth, development and yield in maize and sorghum crops based on historical meteorological data for the municipality of Juranda (2007 to 2013), in the central-west region of Paraná State, Brazil. Treatments were established based on three planting dates in two growing seasons for a group of super early maturity maize hybrids (DKB 330 Pro), and two groups of sorghum hybrids, the first a super early variety (ADV 123) and the second with a normal cycle (1G282). The variables assessed were number of days from planting to flowering, leaf area index (LAI), and 1000 seed weight and yield. Statistical coefficients were used to evaluate calibration accuracy. The results demonstrated that the models were highly efficient at simulating crop cycles, yield and leaf area index, with agreement indices and modeling efficiency values above 0.90 . The results indicated that the CERES-Maize and CERES-Sorghum models generated satisfactory and comparative simulations of maize and sorghum yield for the study area on different planting dates.
\end{abstract}

Keywords: simulation models, succession crop, DSSAT, Zea mays, Sorghum bicolor

\section{Introduction}

The economic viability and agronomic benefits associated with crop rotation are major incentives for growing maize as a succession crop. In different regions, water availability is one of the primary factors considered when establishing preferred growing periods to obtain optimal yields, as well as in agricultural zoning and its applications (Wagner, Jadoski, Maggi, Saito, \& Lima, 2013).

According to data from the Brazilian Crop Supply Agency [CONAB] (CONAB, 2018), maize succession crops produced 9.1 million metric tons over 2.1 million hectares in the 2017/2018 growing season in Paraná state. Despite being well adapted to the region's climate and exhibiting satisfactory yields (Lopez, Erickson, Asseng, \& Bobeda, 2017), sorghum production in the state is low, with an average yield of 3,600 $\mathrm{kg} \mathrm{ha}^{-1}$ in 2018.

Sorghum is rich in nutrients and a staple food in several countries in Africa, South Asia and Central America (Paiva et al., 2017), as well as an important component of animal feed, widely used in the United States, Australia and South America. Its high drought tolerance and resistance to excessive soil moisture have prompted an expansion in its production in relation to other cereals (Zegada-Lizarazu, Zatta, \& Monti, 2012). According to Borghi et al. (2013), sorghum is a good alternative to grain crops in locations with low soil fertility and/or at sites or during periods when maize would perform poorly.

On the other hand, maize is highly responsive to climate variations and therefore affected by planting dates. As such, in Paraná state, delayed planting of maize as a succession crop gradually reduces its yield potential, largely due to lack of light, low temperatures, drought and frost.

Crop simulation models have been used to simulate growth as well as soil carbon, nitrogen and water dynamics, with options to examine the impacts of management practices (planting times, fertilization, irrigation, soil preparation, etc.) and different environmental situations on yield (Liu et al., 2012). 
Dynamic mechanistic models describe daily changes in the plant variables assessed considering the main morphophysiological processes that occur during the simulation period. These simulations are then used to plan optimal management strategies such as planting dates and irrigation practices (Dallacort et al., 2011).

In this respect, a number of authors have used simulation models in different regions around the world to evaluate water availability and its use by plants, either inserting historical climate data into the models or simulating future data, with results indicating similar estimated and actual values (Grossi et al., 2013; Wagner et al., 2013; Kadiyala, Jones, Mylavarapuc, Lic, \& Reddy, 2015; Vivan et al., 2015; Dokoohaki et al., 2016).

Lopez et al. (2017) successfully modified the CERES-Sorghum model in order to better assess root growth and development. The authors highlighted the importance of growing deeper-rooted sorghum cultivars and optimizing planting dates to obtain higher yields.

With a view to providing an alternative for succession crops in Paraná State, this study aimed to assess sorghum and maize crop simulation models based on different planting dates and their effect on crop development.

\section{Method}

Experiments were conducted with maize and sorghum succession crops under dry conditions, using three planting dates in 2014 and 2015, to calibrate the CERES-Maize and CERES-Sorghum models. The study area was located on a farm (Sitio Nossa Senhora Aparecida) in the municipality of Juranda (PR) $\left(24^{\circ} 23^{\prime} 10^{\prime \prime}\right.$ S, $52^{\circ} 49^{\prime} 30^{\prime \prime} \mathrm{W}$ ), at an altitude of $570 \mathrm{~m}$. The soil in the area is predominantly distroferric red latosol (oxisol) (EMBRAPA, 2013), with a humid subtropical climate (Cfa) according to Köppen's classification, average annual temperature of $22.2^{\circ} \mathrm{C}$ and annual rainfall of around $2,100 \mathrm{~mm}$.

Meteorological data were obtained by installing a weather station (Davis Vantage Pro 2) in the study area to determine minimum and maximum temperatures, relativity humidity, solar radiation, rainfall and wind speed.

A database bank of climatological data prior to the study was compiled using information provided by INMET (National Institute of Meteorology), obtained from the automated weather station in Goioerê (PR), the closest city to Juranda (PR), as well as rainfall data collected by the COAMO agribusiness cooperative.

For the sorghum experiments, three planting dates (02/20; 03/02 and 03/12 in 2014 and 02/09; 02/19 and 03/01 in 2015) and three blocks were used.

For the maize crop, three planting dates and four blocks were used in both growing seasons $(02 / 20,03 / 02$ and $03 / 12$ in 2014, and 02/09, 02/19 and 03/01 in 2015); however, harvesting was not possible for the last two dates of 2014 and the last date in 2015 due to wind lodging.

All the plots (maize and sorghum) contained six 6-meter-long rows spaced $0.70 \mathrm{~m}$ apart and the study area of each plot consisted of the two central rows disregarding two meters on either end. Maize was planted using approximately 4.3 seeds per meter, producing a final population of about 56,000 plants per hectare, and sorghum with around 22 seeds per meter, totaling approximately 280,000 plants per hectare.

The following variables were analyzed to calibrate the models:

Number of days from planting and flowering: The plots were visited every three days and the date on which $50 \%$ of plants were releasing pollen was considered the flowering date.

Leaf area index (LAI): the area of each leaf was calculated by adding the maximum length and width and multiplying the amount obtained by a correction factor of 0.75, as described by Francis et al. (1969). The area occupied per plant was determined based on the ratio between the number of plants and the study area of the respective experimental unit. IAF measurements were obtained using the average of two plants per plot.

Yield $\left(\mathrm{kg} \mathrm{h}^{-1}\right)$ : at the end of the experiment, the two $4 \mathrm{~m}$-long center rows $\left(5.6 \mathrm{~m}^{2}\right)$ of each plot were harvested, the panicles threshed and the kernels weighed and then dried in an oven at $65^{\circ} \mathrm{C}$ until constant weight;

1000 seed weight $(1000 \mathrm{SW}-\mathrm{g})$ : Of the kernels used for yield assessment, 1000 from each plot were weighed after oven drying;

Grain filling rate (g): The grain filling rate was calculated for both growing seasons and crops, whereby two panicles were randomly collected and 1000 kernels removed from their center every seven days in 2014 and every ten days in 2015. Total weight was measured (dry weight plus water) and the kernels were then dried in an oven at $65^{\circ} \mathrm{C}$ until constant weight.

LAI during development: In 2015, LAI was calculated every ten days as the crops developed, using the same method as that applied for the final IAF. 
Data from 2014 were used to adjust the genetic coefficients, which were validated with data obtained in 2015. The sorghum experiment was divided into two groups of hybrids: super early maturity (SES) and normal cycle (NS), with the means for each group used to determine the standard deviation. The maize crop was a super early maturing hybrid, analyzed as a single group.

Generalized likelihood uncertainty estimation (GLUE) methodology was applied to calibrate the genetic coefficients of the models, in accordance with He, Dukes, Jones, Graham, and Judge (2009). First, the likely distribution (normal or homogeneous) of the equation parameters is defined. A new distribution is then calculated based on the likely distribution and the data observed, and the new distribution is used to estimate the most likely parameter set and its uncertainties (He et al., 2009). The GLUE method programmed into DSSAT v. 4.5 software (Hoogenboom et al., 2012) was used for initial calibration of the coefficients, with data from the 2014 growing season.

The percent deviations (PD) of the simulated values in relation to the means of the actual data were calculated (Equation 1) during calibration, in addition to modeling efficiency (MEF) statistics (Equation 2) and Willmott's index of agreement (d) (Equation 3):

$$
\begin{gathered}
\mathrm{PD}=\frac{\mathrm{x}-\mathrm{y}}{\mathrm{x}} \times 100 \\
\mathrm{MEF}=1-\frac{\sum_{\mathrm{i} 1}^{\mathrm{n}}\left(\mathrm{x}_{\mathrm{i}}-\mathrm{y}_{\mathrm{i}}\right)^{2}}{\sum_{\mathrm{i}=1}^{\mathrm{n}}\left(\mathrm{x}_{\mathrm{i}}-\overline{\mathrm{x}}\right)^{2}} \\
\mathrm{~d}=1-\frac{\sum_{\mathrm{i}=1}^{\mathrm{n}}\left(\mathrm{y}_{\mathrm{i}}-\mathrm{x}_{\mathrm{i}}\right)^{2}}{\sum_{\mathrm{i}=1}^{\mathrm{n}}\left(\left|\mathrm{y}_{\mathrm{i}}-\overline{\mathrm{x}}\right|+\left|\mathrm{x}_{\mathrm{i}}-\overline{\mathrm{x}}\right|\right)^{2}}
\end{gathered}
$$

Where, $x=$ is the mean of the experimental values; $y=$ the value simulated by the CERES-Maize and CERES-Sorghum models; $\hat{y}=$ the value predicted by regression analysis; $\overline{\mathrm{x}}=$ the mean of $x$; and $n=$ the total amount of data.

According to Tedeschi (2006), the modeling efficiency (MEF) statistic is a good indicator of goodness of fit, with an upper bound of one and (theoretical) lower bound of negative infinity. In a perfect fit, the MEF statistic would result in a value of 1 . Wilmott's index of agreement is used to assess model accuracy and varies from 0 (no agreement) to 1 (perfect agreement).

The CERES-Maize and CERES-Sorghum models were used to simulate the growth and development of a group of super early maturity maize hybrids and two groups of sorghum hybrids (one super early variety (SES) and the other with a normal cycle (NS)) from 2007 to 2013, with different planting dates $(02 / 20,02 / 27,03 / 06,03 / 13$, $03 / 20$ and $03 / 27$ ).

Simulations were performed using historical climatological data from 2007 to 2015, including temperature, relative humidity, wind speed, rainfall and solar radiation, provided by INMET and obtained from the automated weather station in Goioere (PR). Rainfall data were taken from the database of the local agribusiness cooperative. Maximum and minimum temperatures and monthly accumulated rainfall are shown in Figure 1.

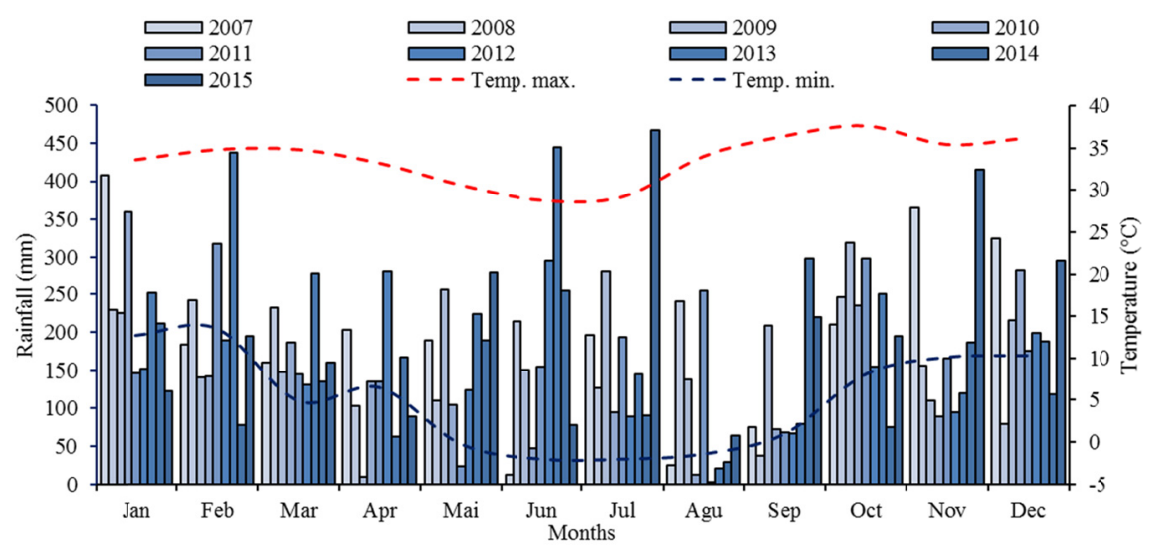

Figure 1. Monthly accumulated rainfall and minimum and maximum temperatures between 2007 and 2015 
Simulations for 2007 to 2015 were performed using the "seasonal" subroutine of DSSAT v. 4.5 software (Hoogenboom et al., 2012), considering a set of historical climatological data and assuming the same initial soil conditions and management practices, and different weather conditions over time.

Six planting dates were simulated $(02 / 20,02 / 27,03 / 06,03 / 13,03 / 20$ and $03 / 27)$ for a group of super early maturity maize hybrids and two groups of sorghum hybrids (one super early variety (SES) and the other with a normal cycle (NS)).

Planting dates were established using the "yield reduction by planting date" methodology described by Amaral et al. (2009). The average yield was calculated for each planting date and simulated year, and then the percent yield decline $\left(\mathrm{P}_{\mathrm{s}}\right)$ in yield in relation to the period with the highest yield (Equation 4).

$$
\mathrm{P}_{\mathrm{s}}=\left(1-\frac{\mathrm{Y}_{\mathrm{s}}}{\mathrm{Y}_{\max }}\right) \times 100
$$

Where, $P S=$ is the percent yield decline for planting date "s"; $Y_{S}=$ the yield for date "s", and $Y_{\max }=$ the maximum yield among all the planting dates assessed.

\section{Results and Discussion}

Although rainfall was recorded year round, monthly accumulated rainfall decreased in April and May, a major problem associated with dry conditions between rains.

Rain normalized between May and June, but average temperature and solar radiation declined, prolonging the crop cycle and affecting yield, as well as exposing the crop to the risk of early frost. The climatological data for the study period (2014 and 2015) are expressed in graph format in Figure 2.
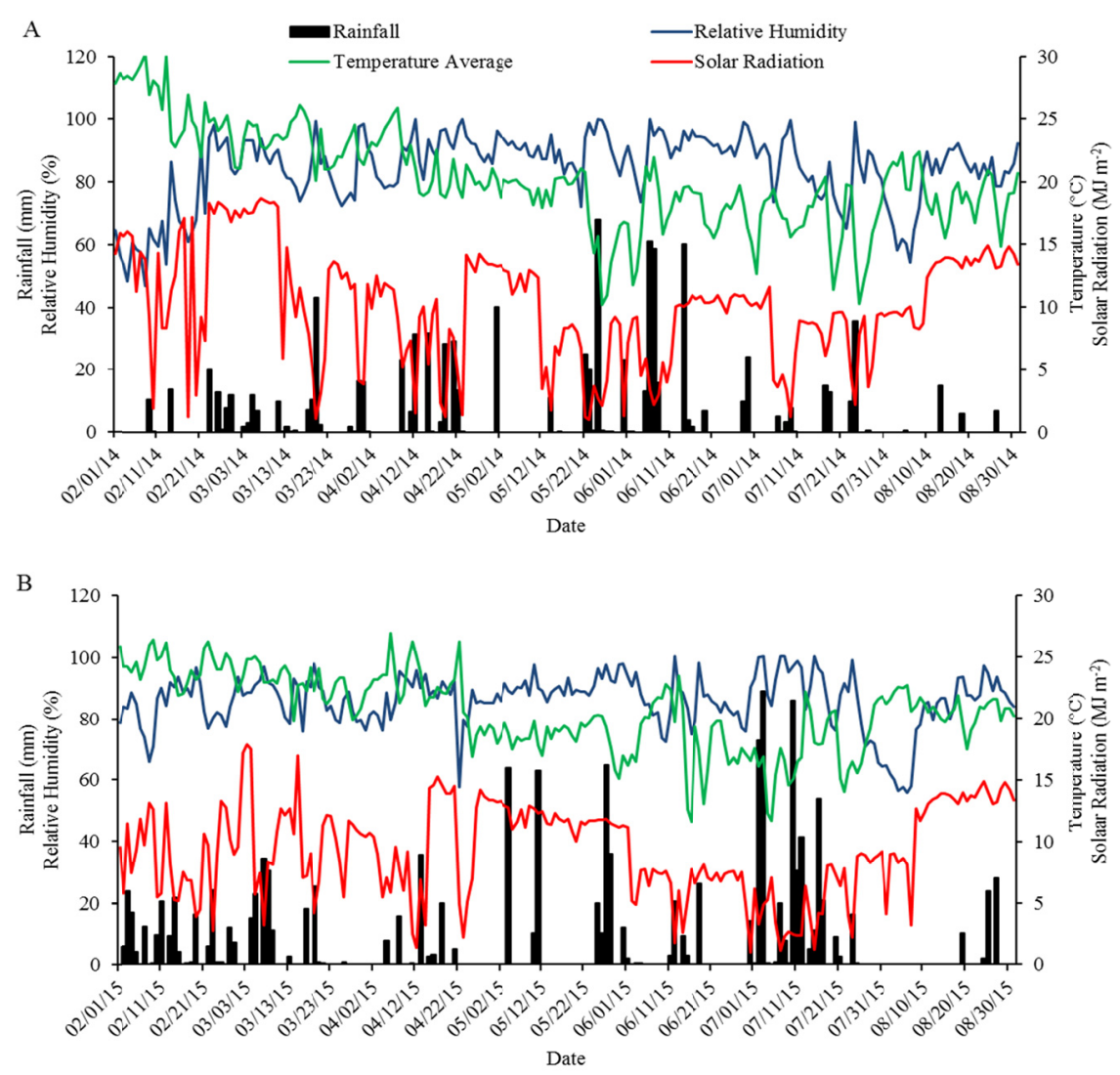

Figure 2. Maximum and minimum temperature and daily rainfall in 2014 (A) and 2015 (B) in Juranda (PR)

Source: Weather station in the study area.

An 11-day drought occurred in May 2014 at the start of the grain filling period, but the average daily temperature fell once the rain resumed. Rainfall declined again at the end of the cycle, primarily affecting later planting dates. Rainfall during the study period was $895 \mathrm{~mm}$. 
There were three 12 to 15 -day periods without rain in 2015. Despite accumulated rainfall of $227 \mathrm{~mm}$ from late March to late May, rain only fell over two short periods, resulting in poor distribution during a critical time for the crops. Total accumulated rainfall in 2015 was $1,209 \mathrm{~mm}$.

After obtaining the climate data for the study period and measurements for the variables assessed, we began adjusting the process of the values recorded and those simulated by the program. However, a comparison of these values indicated the need to adjust coefficients. This was achieved by increasing or decreasing coefficient values until the simulated amounts were closer to those measured within each treatment.

First, data on the phenological growth stages of sorghum and maize were fit to the flowering and physiological maturity dates, and the coefficients of LAI and yield were then adjusted. According to Jones et al. (2003), growth and development parameters are interdependent, which corroborates the calibration sequence followed.

Simulation planning considered two scenarios, one for potential production (without drought stress) and another for actual production governed by rainfall during the simulated period.

In potential production simulations, the model assumed that water was not a limiting factor, that is, yield was largely dependent on other climate elements, such as solar radiation and temperature. This makes it possible to analyze the influence of these climate factors on the yield of sorghum and maize succession crops as a function of planting date.

For the actual production scenario, simulation was based on the climate data input into the software, whereby crop water needs were only met by rainfall recorded in the climatological database. This enabled us to evaluate the effect of water availability on the crop at different growth stages, which, depending on the planting date, influenced establishment, phenology and yield.

Bao, Hoogenboom, McClendon, and Vellidis (2017) calibrated the genetic coefficients of the CERES-Maize model for different maize cultivars using only variables related to yield and harvest dates and found a difference of only $3 \%$ for calibration and $8 \%$ for validation in relation to actual data, in a 54-year study at six different locations.

Singh et al. (2014) reported that sorghum crops are better able to adapt to drought than an increase in the average temperature. Grossi, Justino, Rodrigues, and Andrade (2015) concluded that sorghum yield is less affected by wind and relative humidity and more sensitive to water availability and solar radiation.

Sutka, Manzur, Vitali, Micheletto, and Amodeo (2016) studied the physiological response of two sorghum genotypes to drought based on different morphological and physiological root and shoot traits and observed a differential response between the two, indicating plasticity in water management under drought conditions during the seedling stage, with particularly noteworthy responses by whole plants to soil moisture deficits. Different drought tolerance strategies have also been reported in sorghum hybrids by Yi et al. (2014) and Fracasso, Trindade, and Amaducci (2016).

Calibrating the coefficients between the actual and simulated crop development values generated the genetic coefficients representing the crops in the DSSAT program (Tables 1 and 2).

Table 1. Calibrated genetic coefficient values for maize crops in the CERES-Maize model for the 2014 growing season

\begin{tabular}{lll}
\hline Genetic coefficient & Calibrated value & Unit of measurement \\
\hline P1 & 238.00 & ${ }^{\circ} \mathrm{C}$ day \\
P2 & 0.50 & ${ }^{\circ} \mathrm{C}$ day \\
P5 & 675.00 & ${ }^{\circ} \mathrm{C}$ day \\
G2 & 980.00 & Dimensionless \\
G3 & 10.50 & $\mathrm{mg}$ day \\
PHINT & 38.90 & ${ }^{\circ} \mathrm{C}$ day \\
\hline
\end{tabular}

Note. P1: duration of the vegetative stage, based on the thermal sum from emergence to the end of the juvenile phase (base temperature of $8{ }^{\circ} \mathrm{C}$ ); P2: sensitivity to the photoperiod, based on the delay in days until the onset of male flowering for every one hour increase in the photoperiod after 12.5 hours; P5: duration of the reproductive stage, based on the thermal sum from stigma emergence to physiological maturity (base temperature of $8{ }^{\circ} \mathrm{C}$ ); $\mathrm{G} 2$ : number of kernels per plant; G3: grain filling rate under optimal growth conditions; PHINT: phyllocron interval corresponding to the time between the emergence of successive leaves. 
Table 2. Calibrated genetic coefficient values for the two hybrid sorghum groups in the CERES-Sorghum model for the 2014 growing season

\begin{tabular}{llll}
\hline \multirow{2}{*}{ Genetic coefficient } & \multicolumn{2}{c}{ Calibrated Values } & \multirow{2}{*}{ Unit of measurement } \\
\cline { 2 - 3 } & Group 1 & Group 2 & \\
\hline P1 & 626.00 & 714.00 & ${ }^{\circ} \mathrm{C}$ day \\
P2 & 102.00 & 102.00 & ${ }^{\circ} \mathrm{C}$ day \\
P2O & 11.90 & 12.20 & $\mathrm{H}$ \\
P2R & 100.00 & 100.00 & ${ }^{\circ} \mathrm{C}$ day h \\
PANTH & 77.50 & 99.00 & ${ }^{\circ} \mathrm{C}$ day \\
P3 & 152.50 & 152.50 & ${ }^{\circ} \mathrm{C}$ day \\
P4 & 81.50 & 81.50 & ${ }^{\circ} \mathrm{C}$ day \\
P5 & 650.00 & 650.00 & ${ }^{\circ} \mathrm{C}$ day \\
PHINT & 49.00 & 49.00 & ${ }^{\circ} \mathrm{C}$ day leaf \\
G1 & 6.00 & 1.00 & Dimensionless \\
G2 & 17.00 & 10.90 & Dimensionless \\
\hline
\end{tabular}

Note. P1: Thermal time during which plants did not respond to photoperiod changes, with duration from seedling emergence to the end of the juvenile phase; P2: thermal time from the end of the juvenile phase to panicle initiation, under short days; P2O: photoperiod limit above which the thermal time for panicle initiation is affected by the photoperiod; P2R: rate at which the thermal time for panicle initiation increases for every hour added to the photoperiod above P2O; PANTH: thermal time from the end of panicle initiation to flowering; P3: thermal time from the end of flag leaf expansion to flowering; P4: thermal time from flowering to the onset of grain filling; P5: thermal time from the onset of grain filling to physiological maturity; PHINT: phyllocron interval corresponding to the time between the emergence of successive leaves; G1: coefficient expressing the relative leaf size; G2: fraction of photoassimilates distributed to the panicle.

Calibration of the genetic coefficients was followed by the simulation of crop growth, development and yield. Table 3 shows the calibration results for the CERES-Maize model for 2014 and 2015.

Table 3. Actual and simulated values to assess CERES-Maize model calibration for the 2014 and 2015 growing seasons and the respective percent deviations, modeling efficiency (MEF) statistics and index of agreement

\begin{tabular}{|c|c|c|c|c|c|c|c|}
\hline Treatment & Variable & Actual Mean Value & Simulated Value & Standard Deviation & Percent Deviation & MEF & d \\
\hline $1-(02 / 20 / 2014)$ & Flowering (days) & 57.50 & 60.00 & 1.25 & 4.35 & & \\
\hline $2-(03 / 02 / 2015)$ & Flowering (days) & 61.45 & 60.00 & 0.73 & -2.36 & -0.0458 & 0.7172 \\
\hline $3-(03 / 12 / 2015)$ & Flowering (days) & 59.55 & 60.00 & 0.23 & 0.76 & & \\
\hline $1-(02 / 20 / 2014)$ & LAI & 3.21 & 2.72 & 0.25 & -15.26 & & \\
\hline $2-(03 / 02 / 2015)$ & LAI & 3.06 & 2.75 & 0.16 & -10.13 & -0.9477 & 0.7450 \\
\hline $3-(03 / 12 / 2015)$ & LAI & 3.36 & 2.66 & 0.35 & -20.83 & & \\
\hline $1-(02 / 20 / 2014)$ & $1000 \mathrm{SW}(\mathrm{g})$ & 346.40 & 253.30 & 46.55 & -26.88 & & \\
\hline $2-(03 / 02 / 2015)$ & $1000 \mathrm{SW}(\mathrm{g})$ & 263.00 & 431.10 & 84.05 & 63.92 & -0.7294 & 0.6332 \\
\hline $3-(03 / 12 / 2015)$ & $1000 \mathrm{SW}(\mathrm{g})$ & 249.10 & 336.40 & 43.65 & 35.05 & & \\
\hline $1-(02 / 20 / 2014)$ & Yield $\left(\mathrm{kg} \mathrm{ha}^{-1}\right)$ & 5988.11 & 5934.00 & 27.05 & -0.90 & & \\
\hline $2-(03 / 02 / 2015)$ & Yield $\left(\mathrm{kg} \mathrm{ha}^{-1}\right)$ & 7926.88 & 7968.00 & 20.56 & 0.52 & 0.9380 & 0.9874 \\
\hline $3-(03 / 12 / 2015)$ & Yield $\left(\mathrm{kg} \mathrm{ha}^{-1}\right)$ & 6693.04 & 7191.00 & 248.98 & 7.44 & & \\
\hline
\end{tabular}

Considering the results obtained for the variables studied in terms of the relationship between actual and simulated values, positive percent deviations (PD) indicate overestimation and negative PD underestimation.

Based on an analysis of the data (Table 3), the CERES-Maize model shows a good fit to the data, suggesting good accuracy in simulating maize growth and development. This is supported by the agreement indices and MEF values obtained in calibration for 2014 and validation in 2015, with yield values greater than 0.9. The model exhibited low efficiency in simulating the flowering period since cultivation over a two-year period increased crop cycle variation. 
The variables with the best fit for maize were flowering date and yield, whereas Kadiyala et al. (2015) reported the best agreement indices and MEF statistics for physiological maturity date and shoot dry weight. Leaf area index (LAI) was underestimated in simulations, with values up to $20 \%$ lower than those observed in the field (Table 3), and 1000 seed weight displayed the worst fit, with over $60 \%$ variation. Pereira, Von Pinho, Paglis, Pereira and Altoé (2010) studied maize crops with three different planting dates in Lavras, Minas Gerais state, Brazil, using the CERES-Maize model and also obtained low statistical indices for number of seeds and 1000 seed weight, with a better fit for flowering and physiological maturity dates, yield components and yield.

Analysis of the goodness of fit of the CERES-Sorghum model for the two sorghum hybrids shows agreement index values greater than 0.90 for almost all the variables except 1000SW, which, despite an MEF of 0.72 , indicates good model efficiency (Table 4). The PF for these treatments was very high, particularly for yield. The results suggest that factors other than those analyzed and simulated influenced yield on the last planting date. A high incidence of disease in some cultivars is assumed to be the main indicator, even with protective management practices, corroborating the findings of Grossi et al. (2013).

Table 4. Actual and simulated values to assess CERES-Sorghum model calibration for the 2014 growing season and the respective percent deviations, modeling efficiency (MEF) statistics and index of agreement.

\begin{tabular}{|c|c|c|c|c|c|c|c|}
\hline Treatment & Variable & Actual Mean Value & Simulated Value & Standard Deviation & Percent Deviation & MEF & d \\
\hline 1-(02/20/2014)SES & Flowering (days) & 59.67 & 62 & 1.165 & 3.90 & \multirow{6}{*}{0.8250} & \multirow{6}{*}{0.9796} \\
\hline 2-(03/02/2014)SES & Flowering (days) & 62.84 & 61 & 2.165 & -6.34 & & \\
\hline 3-(03/12/2014)SES & Flowering (days) & 68.33 & 64 & 1.335 & -3.83 & & \\
\hline 4-(02/20/2014)NS & Flowering (days) & 67.17 & 66 & 0.920 & -2.93 & & \\
\hline 5-(03/02/2014)NS & Flowering (days) & 69.67 & 67 & 0.585 & -1.74 & & \\
\hline 6-(03/12/2014)NS & Flowering (days) & 72.50 & 73 & 0.250 & 0.69 & & \\
\hline $1-(02 / 20 / 2014) S E S$ & LAI & 3.45 & 3.72 & 0.138 & 7.98 & \multirow{6}{*}{0.0724} & \multirow{6}{*}{0.9141} \\
\hline 2-(03/02/2014)SES & LAI & 2.82 & 2.83 & 0.005 & 0.35 & & \\
\hline 3-(03/12/2014)SES & LAI & 2.20 & 3.63 & 0.718 & 65.38 & & \\
\hline 4-(02/20/2014)NS & LAI & 4.31 & 3.96 & 0.175 & -8.12 & & \\
\hline 5-(03/02/2014)NS & LAI & 2.99 & 4.03 & 0.523 & 35.01 & & \\
\hline 6-(03/12/2014)NS & LAI & 2.99 & 3.79 & 0.400 & 26.76 & & \\
\hline $1-(02 / 20 / 2014) S E S$ & $1000 \mathrm{SW}(\mathrm{g})$ & 0.0249 & 0.0249 & 0.000 & -0.19 & \multirow{6}{*}{-0.3336} & \multirow{6}{*}{0.7836} \\
\hline 2-(03/02/2014)SES & $1000 \mathrm{SW}(\mathrm{g})$ & 0.0254 & 0.0204 & 0.002 & -19.58 & & \\
\hline 3-(03/12/2014)SES & $1000 \mathrm{SW}(\mathrm{g})$ & 0.0251 & 0.0219 & 0.002 & -12.74 & & \\
\hline 4-(02/20/2014)NS & $1000 \mathrm{SW}(\mathrm{g})$ & 0.0250 & 0.0239 & 0.001 & -4.27 & & \\
\hline 5-(03/02/2014)NS & 1000SW (g) & 0.0226 & 0.0299 & 0.004 & 32.15 & & \\
\hline 6-(03/12/2014)NS & $1000 \mathrm{SW}(\mathrm{g})$ & 0.0255 & 0.0284 & 0.001 & 12.00 & & \\
\hline $1-(02 / 20 / 2014) S E S$ & Yield $\left(\mathrm{kg} \mathrm{ha}^{-1}\right)$ & 4875.39 & 5390.00 & 257.31 & 10.56 & \multirow{6}{*}{-0.0506} & \multirow{6}{*}{0.9192} \\
\hline 2-(03/02/2014)SES & Yield $\left(\mathrm{kg} \mathrm{ha}^{-1}\right)$ & 4493.99 & 4669.00 & 87.51 & 3.89 & & \\
\hline 3-(03/12/2014)SES & Yield $\left(\mathrm{kg} \mathrm{ha}^{-1}\right)$ & 3104.63 & 4819.00 & 857.18 & 55.22 & & \\
\hline $4-(02 / 20 / 2014) \mathrm{NS}$ & Yield $\left(\mathrm{kg} \mathrm{ha}^{-1}\right)$ & 5089.91 & 5248.00 & 79.04 & 3.11 & & \\
\hline 5-(03/02/2014)NS & Yield $\left(\mathrm{kg} \mathrm{ha}^{-1}\right)$ & 4507.71 & 4949.00 & 220.65 & 9.79 & & \\
\hline 6-(03/12/2014)NS & Yield $\left(\mathrm{kg} \mathrm{ha}^{-1}\right)$ & 2132.27 & 4745.00 & 1306.37 & 122.53 & & \\
\hline
\end{tabular}

Simulation data for 2015 are presented in Table 5. Chimonyo, Modi and Mabhaudhy (2016) also found that actual data were influenced by uncontrolled environmental factors, with hail affecting the number of leaves and $\mathrm{LAI}$ in an experiment with sorghum and cowpea.

In 2015, PD for flowering date (Table 5) was very similar to the maize adjustment. The super early sorghum hybrids (SES) obtained lower flowering date values than those observed for the normal variety (N) (Tables 4 and 5), likely due to the temperature and photoperiod. 
Table 5. Actual and simulated values for CERES-Sorghum model calibration in the 2015 growing season and their respective percent deviations, modeling efficiency (MEF) statistics and index of agreement

\begin{tabular}{|c|c|c|c|c|c|c|c|}
\hline Treatment & Variable & Actual Mean Value & Simulated Value & Standard Deviation & Percent Deviation & MEF & d \\
\hline 7-(02/09/2015)SES & Flowering (days) & 62.33 & 63.00 & 0.33 & 1.07 & \multirow{6}{*}{0.2016} & \multirow{6}{*}{0.8829} \\
\hline 9-(02/19/2015)SES & Flowering (days) & 64.50 & 62.00 & 1.25 & -3.88 & & \\
\hline 11-(03/01/2015)SES & Flowering (days) & 61.67 & 63.00 & 0.67 & 2.16 & & \\
\hline 8-(02/09/2015)NS & Flowering (days) & 63.00 & 65.00 & 1.00 & 3.17 & & \\
\hline $10-(02 / 19 / 2015) \mathrm{NS}$ & Flowering (days) & 65.83 & 65.00 & 0.42 & -1.27 & & \\
\hline 12-(03/01/2015)NS & Flowering (days) & 64.33 & 70.00 & 2.83 & 8.81 & & \\
\hline 7-(02/09/2015)SES & LAI & 3.56 & 3 & 0.279 & -15.66 & \multirow{6}{*}{0.2927} & \multirow{6}{*}{0.9250} \\
\hline 9-(02/19/2015)SES & LAI & 3.43 & 3.02 & 0.206 & -11.98 & & \\
\hline 11-(03/01/2015)SES & LAI & 3.01 & 2.7 & 0.157 & -10.40 & & \\
\hline 8-(02/09/2015)NS & LAI & 3.92 & 3.42 & 0.251 & -12.81 & & \\
\hline $10-(02 / 19 / 2015) \mathrm{NS}$ & LAI & 4.09 & 3.41 & 0.341 & -16.67 & & \\
\hline $12-(03 / 01 / 2015) \mathrm{NS}$ & LAI & 3.60 & 3.69 & 0.047 & 2.64 & & \\
\hline 7-(02/09/2015)SES & $1000 \mathrm{SW}(\mathrm{g})$ & 0.0250 & 0.0371 & 0.006 & 48.32 & \multirow{6}{*}{0.0280} & \multirow{6}{*}{0.7479} \\
\hline 9-(02/19/2015)SES & $1000 \mathrm{SW}(\mathrm{g})$ & 0.0249 & 0.0233 & 0.001 & -6.40 & & \\
\hline 11-(03/01/2015)SES & $1000 \mathrm{SW}(\mathrm{g})$ & 0.0256 & 0.0231 & 0.001 & -9.62 & & \\
\hline $8-(02 / 09 / 2015) \mathrm{NS}$ & $1000 \mathrm{SW}(\mathrm{g})$ & 0.0240 & 0.0224 & 0.001 & -6.58 & & \\
\hline $10-(02 / 19 / 2015) \mathrm{NS}$ & $1000 \mathrm{SW}(\mathrm{g})$ & 0.0232 & 0.0239 & 0.000 & 3.00 & & \\
\hline 12-(03/01/2015)NS & 1000SW (g) & 0.0253 & 0.0205 & 0.002 & -18.85 & & \\
\hline 7-(02/09/2015)SES & Yield $\left(\mathrm{kg} \mathrm{ha}^{-1}\right)$ & 5675.45 & 5456.00 & 109.72 & -3.87 & \multirow{6}{*}{0.6354} & \multirow{6}{*}{0.9333} \\
\hline 9-(02/19/2015)SES & Yield $\left(\mathrm{kg} \mathrm{ha}^{-1}\right)$ & 6253.46 & 5747.00 & 253.23 & -8.10 & & \\
\hline 11-(03/01/2015)SES & Yield $\left(\mathrm{kg} \mathrm{ha}^{-1}\right)$ & 5450.58 & 4928.00 & 261.29 & -9.59 & & \\
\hline 8-(02/09/2015)NS & Yield $\left(\mathrm{kg} \mathrm{ha}^{-1}\right)$ & 5945.48 & 5493.00 & 226.24 & -7.61 & & \\
\hline $10-(02 / 19 / 2015) \mathrm{NS}$ & Yield $\left(\mathrm{kg} \mathrm{ha}^{-1}\right)$ & 5471.05 & 5515.00 & 21.97 & 0.80 & & \\
\hline $12-(03 / 01 / 2015) \mathrm{NS}$ & Yield $\left(\mathrm{kg} \mathrm{ha}^{-1}\right)$ & 3827.90 & 4731.00 & 451.55 & 23.59 & & \\
\hline
\end{tabular}

Maximum temperatures from planting until flowering declined by an average of $2.0^{\circ} \mathrm{C}$ every ten days between planting dates for the two-year study period (Figures 2A and 2B). These high initial temperatures meant the accumulated thermal sum needed for flowering was reached more quickly.

Akinseye et al. (2017) compared three sorghum growth simulation models and concluded that SAMARA was better able to predict LAI than APSIM and DSSAT, although the last two models showed greater accuracy for grain yield and biomass production, which may explain the values found here and in the two aforementioned studies.

Yield exhibited a low PD, with simulated values within the standard deviation of actual data. Similarly, Singh et al. (2014) obtained Willmott agreement indices (d) above 0.95 for the yield of three sorghum hybrids grown in two regions of India, with $\mathrm{r}^{2}$ greater than or equal to 0.85 .

The difficulty in fitting the model to experimental data can be attributed to experimental error resulting from sampling problems and the frequency needed to obtain realistic values, as well as difficulty keeping the kernels collected before physiological maturation intact and dry weight loss during oven drying.

Genetic coefficients are interconnected in model calibration, making it impossible to change an individual variable since one may be a better fit than another. In the present study, 1000SW was considered a secondary variable. Leaf area index showed a better fit than 1000SW, as shown in Figure 3. 


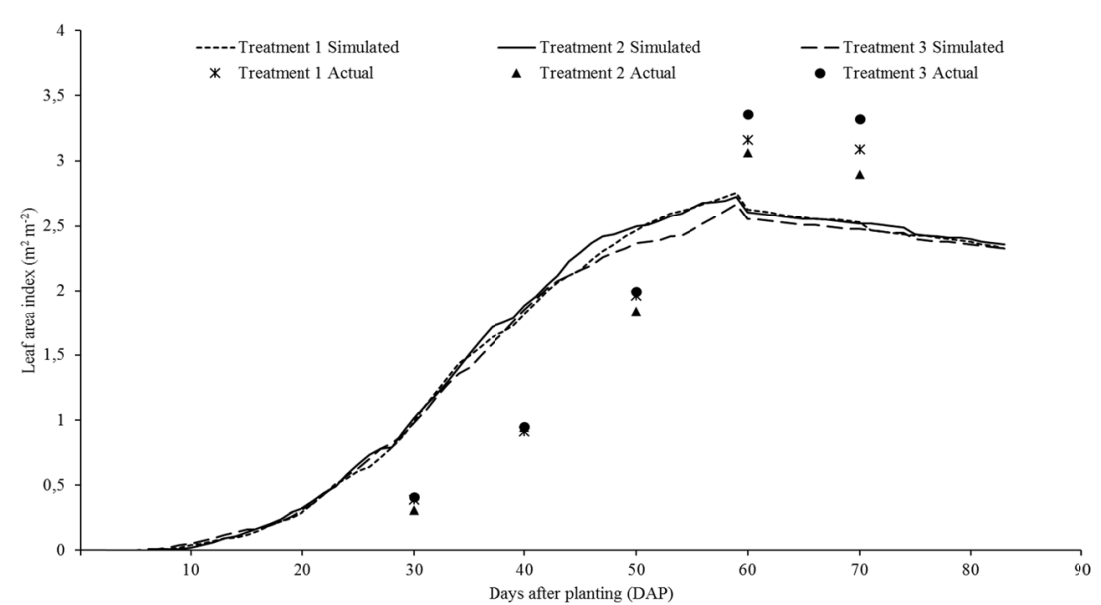

Figure 3. Actual and simulated Leaf Area Index (LAI) for the CERES-Maize model in a maize succession crop grown in 2015 in Juranda (PR)

Analysis of Figure 4 indicates that the simulated line for the first treatments is closer to the points observed in the field, although all treatments obtained a high agreement index (above 0.96). The first planting date (treatments 7 and 8) showed a better fit to the actual data, with MEF greater than 0.80 . Thus, the model was able to satisfactorily simulate LAI behavior and development for the two sorghum hybrids with different planting dates.
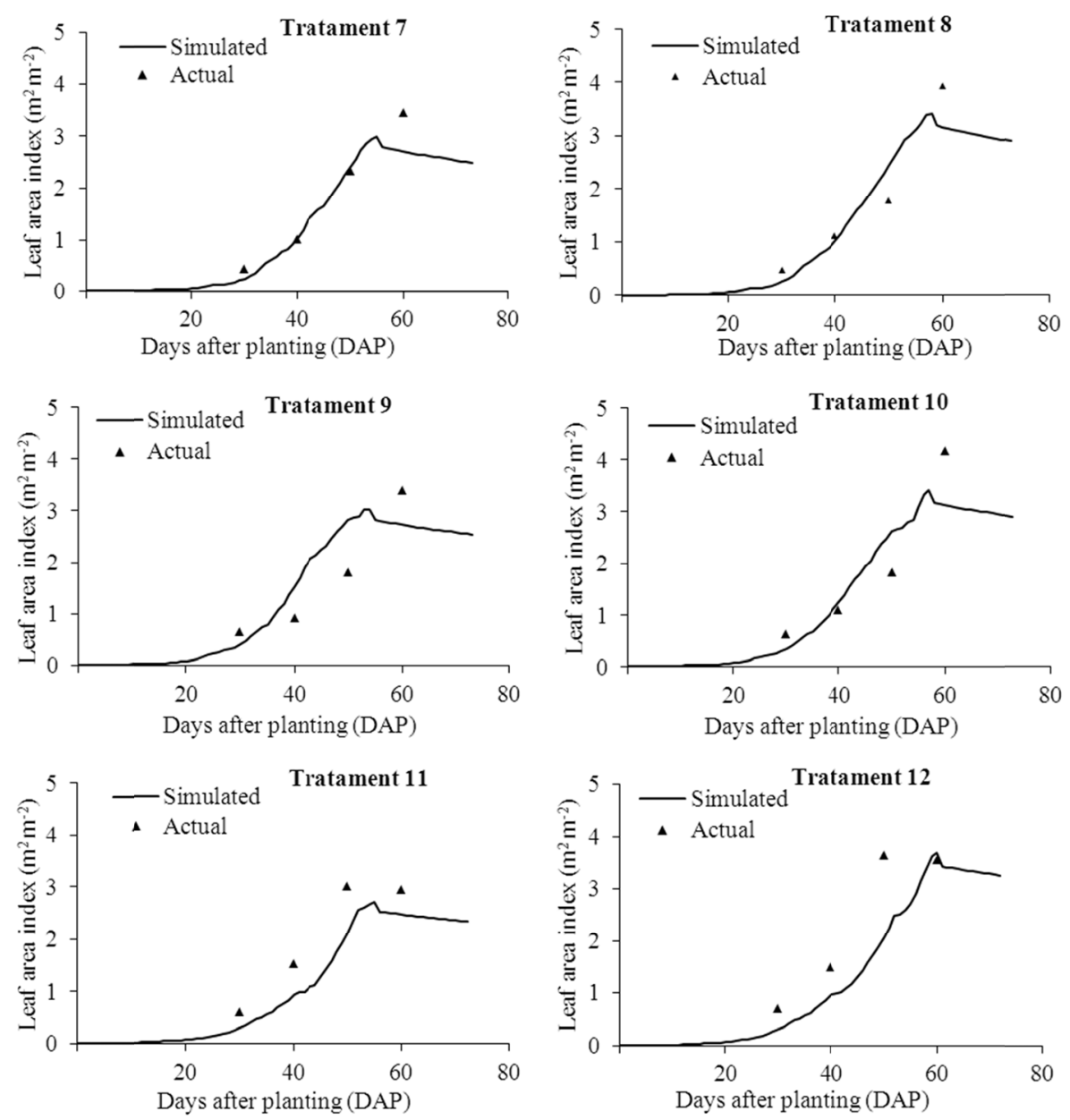

Figure 4. Leaf area index simulated by the CERES-Sorghum model for two sorghum hybrids grown as succession crops in Juranda (PR) 
It is important to underscore that the models depict average conditions and cannot always capture significant deviations in the actual data, since measures and repetitions vary in field experiments, which is reflected in standard deviation values. Nevertheless, the models were efficient at simulating flowering, LAI and seed yield in maize and sorghum for different planting dates.

Their limitations did not prevent them from correctly simulating data on plant phenology, such as the number of days until flowering, maximum LAI and crop yield, at times under or overestimating these variables, but with low percent deviations and within the standard deviation for actual data.

As expected, in the sorghum crop the normal hybrids (group 2) took longer to flower and reach maturity, whereas group 1 (super early) behaved similarly to the maize crop (Figure 5).

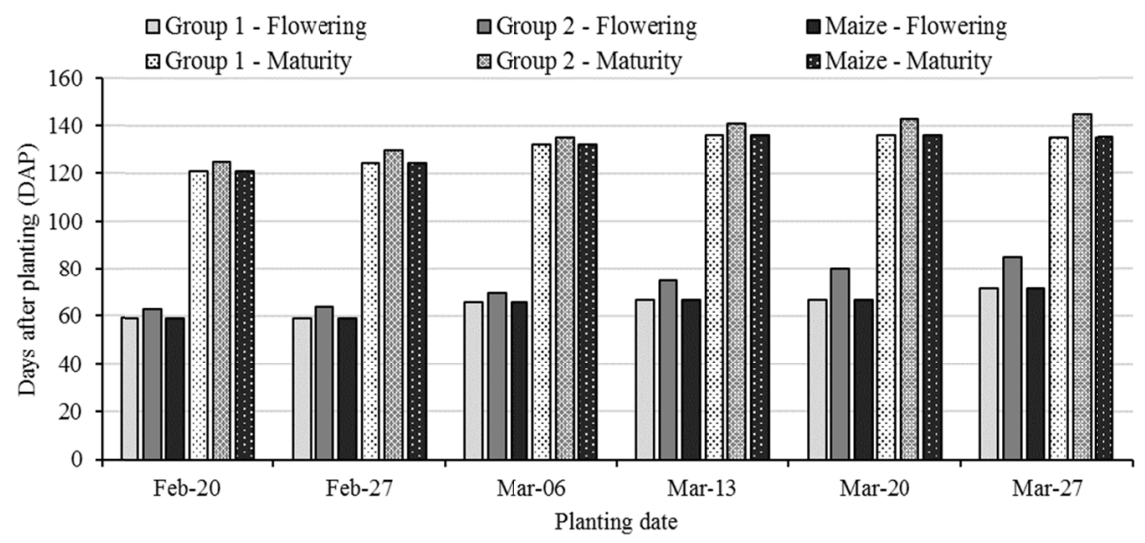

Figure 5. Average number of days until flowering and physiological maturity in two hybrid sorghum varieties (group 1 and group 2) and a maize crop

In both crops, planting performed from March onwards resulted in an average increase of 10 to 15 days until flowering and physiological maturity, meaning plants were exposed to biotic and abiotic stresses in the field for longer. This is largely because the later the planting date, the greater the accumulation of growing degree days (GDD) due to the decline in average temperatures.

Simulated maize yield under real climate conditions in the years studied are shown in Figure 6.

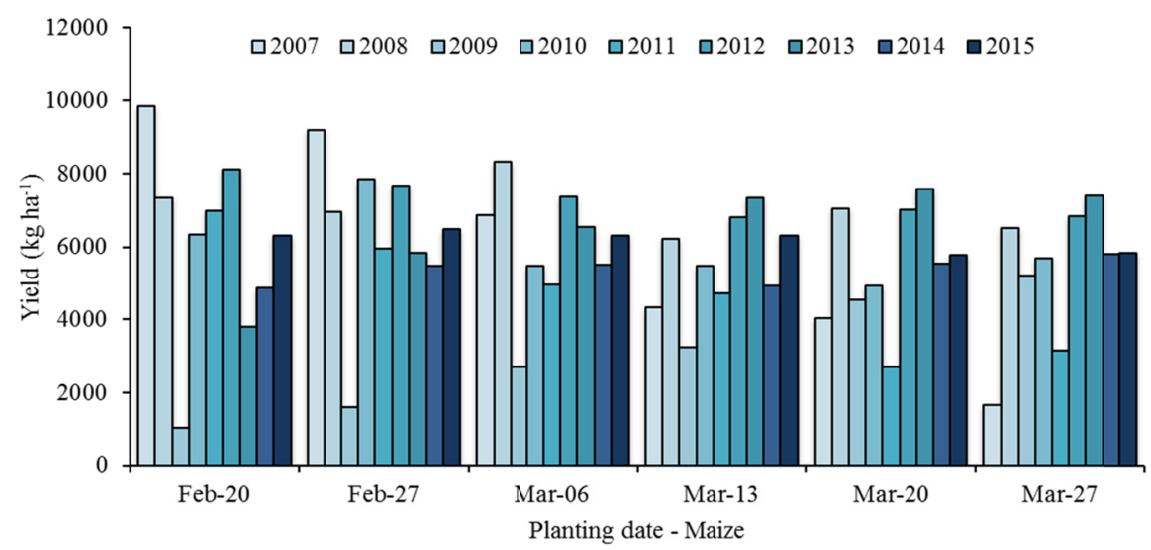

Figure 6. Simulated maize yield with different planting dates for 2007 to 2013

Figure 6 indicates a trend of smaller yields per area the later the planting date. However, the opposite occurred in 2009, when yield was higher the later in March that planting was performed due to the low rainfall accumulation in April (Figure 1). This significant water shortage during the grain filling stage probably limited yield. The last planting dates showed improvements as rainfall resumed in May. Similar behavior was also observed in 2013, albeit less severe than in 2009. 
In order to prevent these drought-related losses (Figure 6), prevention strategies such as different planting dates should be adopted, using super early hybrids or breeding programs to develop cultivars that minimize the effect of water stress on grain filling (Heinemann, Andrade, Gomide, Amorim, \& Paz, 2009).

The results obtained for sorghum simulation under real climate conditions in the years studied are presented in Figure 7. According to Figure 7, although its yield 'ceiling' is lower than that of maize, sorghum maintains yield stability for different planting dates. Nevertheless, yield declined in 2009 due to drought stress, albeit not as intense as that experienced by the maize crop. Lack of rain in 2013 also influenced yield for the earlier planting dates.

In the sorghum simulation, low temperatures in 2007 and severe frost in May resulted in the loss of the entire crop, since sorghum is more sensitive to these conditions than maize. The normal hybrids in group II were more affected by drought stress and low temperatures than group I.
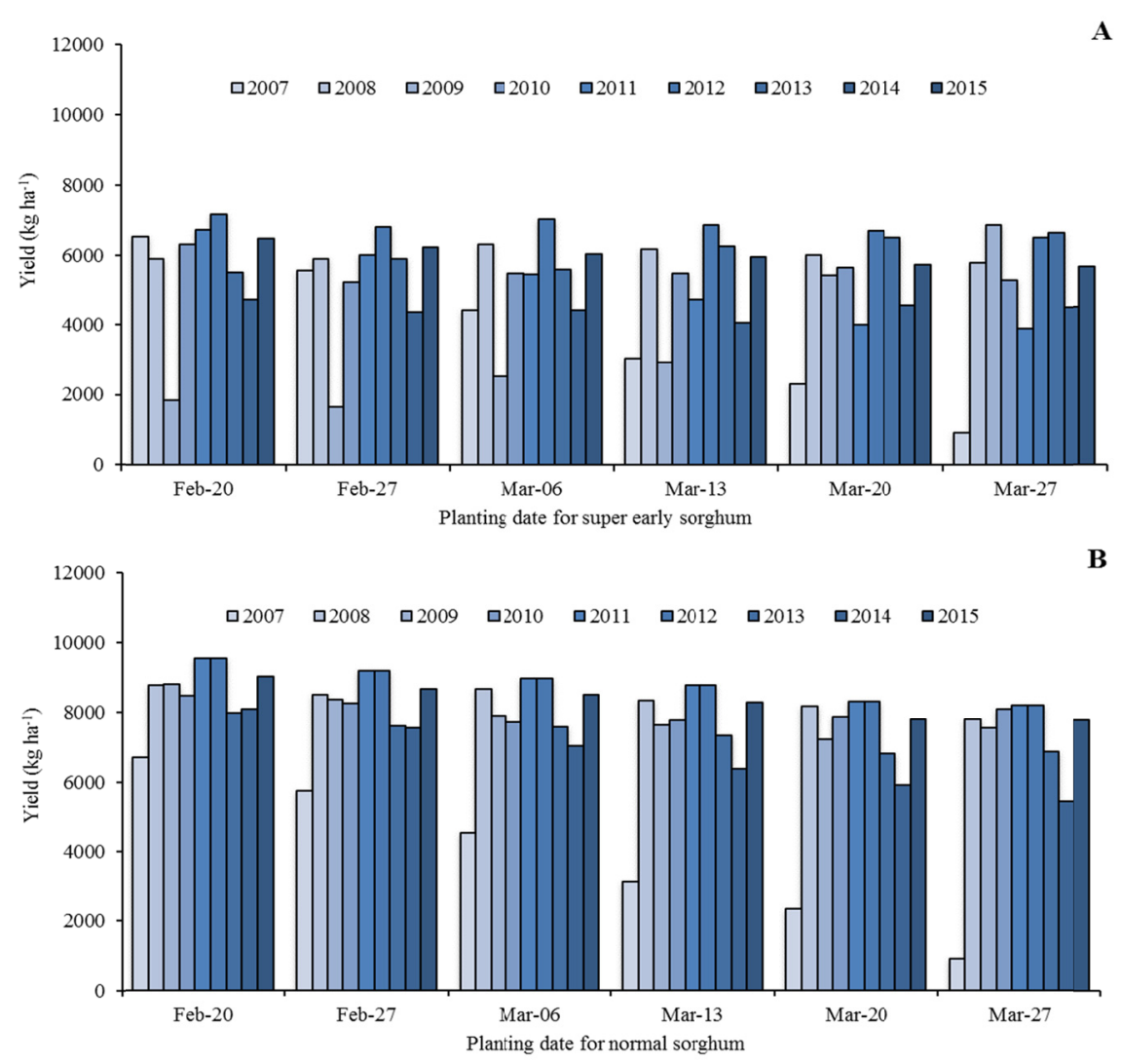

Figure 7. Simulated yield for super early (A) and normal (B) sorghum hybrids with different planting dates from 2007 to 2015

For potential yield simulations, cumulative probability graphs were generated for the maize crop (Figure 8). 


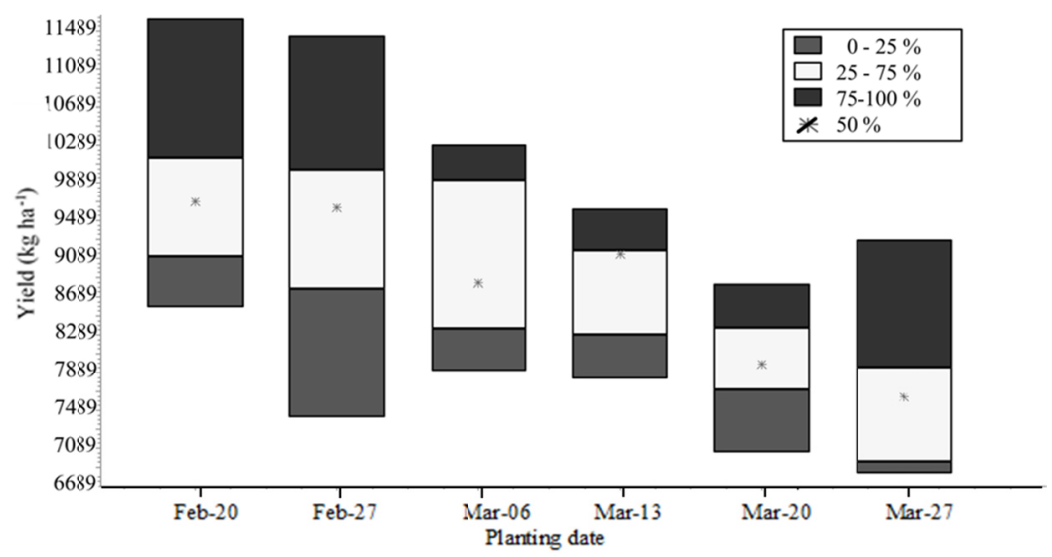

Figure 8. Yield potential for the maize crop on different planting dates

The maximum potential yield (over $11,400 \mathrm{~kg} \mathrm{ha}^{-1}$ ) for maize occurred for planting on $02 / 20$, although these values decline over time without drought stress, which demonstrates the effects of temperature and light. There is a possibility that this yield will occur for cumulative probability of $75 \%$, that is, in three out of four years. The initial yield is $10,000 \mathrm{~kg} \mathrm{ha}^{-1}$, remaining stable for the first three planting dates and then slowly decreasing to $8,000 \mathrm{~kg} \mathrm{ha}^{-1}$ on $03 / 27$.

The simulated potential yields found here are similar to those reported by other authors. Cardoso et al. (2004) recorded an average potential yield of around $10,000 \mathrm{~kg} \mathrm{~h}^{-1}$ for planting in early January and about $6,000 \mathrm{~kg}$ $\mathrm{ha}^{-1}$ in March. Heinemann et al. (2009) simulated summer maize crops and obtained a potential yield of 7,300 $\mathrm{kg}$ $\mathrm{ha}^{-1}$, with an average of $8,300 \mathrm{~kg} \mathrm{ha}^{-1}$ for the succession crop.

Sorghum (Figure 9) showed greater stability for maximum potential yield $\left(9,500\right.$ to $\left.8,300 \mathrm{~kg} \mathrm{ha}^{-1}\right)$ and cumulative probabilities of $50 \%\left(8,500\right.$ to $\left.7,500 \mathrm{~kg} \mathrm{ha}^{-1}\right)$ and $75 \%\left(9,000\right.$ to $\left.8,000 \mathrm{~kg} \mathrm{ha}^{-1}\right)$ the later the planting date. Yield declined significantly at lower cumulative probabilities due to the minimum temperatures that crops can withstand during grain filling when planted late. The two hybrid groups behaved similarly, albeit with lower yields recorded for group II.

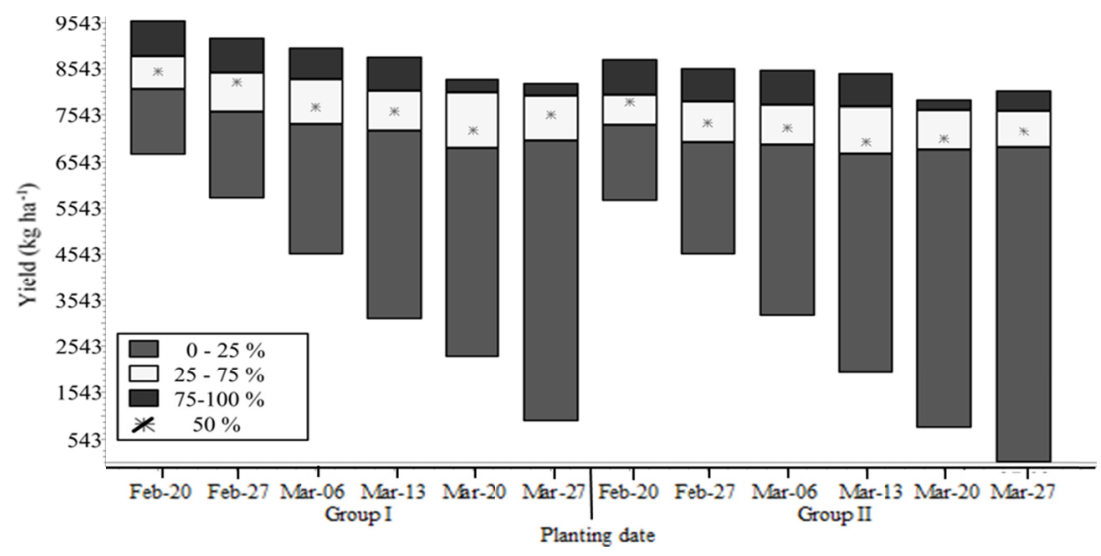

Figure 9. Potential yield for two sorghum hybrids with different planting dates

Houx III and Fritschi (2015) also observed a decline in sorghum yield at different planting dates, with similar results between hybrids, likely due to less efficient use of solar radiation, low temperatures and the shorter photoperiod in early October, corroborating our findings.

The smaller reduction in actual compared to simulated sorghum yield in relation to maize can be attributed to better water use by sorghum plants. This is evident in the results obtained by Piccinni, Ko, Marek, and Howell (2009), who measured the crop coefficient (Kc) in both crops and found that maize uses up to $20 \%$ more water than sorghum during grain filling, which requires the most water. Rosa, Ramos, and Pereira (2016) obtained a $15 \%$ higher dual $\mathrm{Kc}$ in maize when compared to sorghum, with both crops grown in saline soil. 
Based on the yield reduction by planting date methodology, potential and actual yield values were calculated to determine the optimal planting date for maize and sorghum (Table 6).

Table 6. Percent yield decline by planting date.

\begin{tabular}{|c|c|c|c|c|c|c|}
\hline \multirow{2}{*}{ Planting Date } & \multicolumn{2}{|c|}{ Sorghum Group I } & \multicolumn{2}{|c|}{ Sorghum Group II } & \multicolumn{2}{|c|}{ Maize } \\
\hline & Potential & Actual & Potential & Actual & Potential & Actual \\
\hline Fev-20 & 0.0 & 13.8 & 0.0 & 17.7 & 0.5 & 23.1 \\
\hline Fev-27 & 5.5 & 20.1 & 5.3 & 16.6 & 4.1 & 19.6 \\
\hline Mar-6 & 10.3 & 20.7 & 8.6 & 18.2 & 7.4 & 23.0 \\
\hline Mar-13 & 14.4 & 23.5 & 12.5 & 19.1 & 10.1 & 28.8 \\
\hline Mar-20 & 18.7 & 21.3 & 15.6 & 18.2 & 18.1 & 28.4 \\
\hline Mar-27 & 20.4 & 23.0 & 16.2 & 22.5 & 21.5 & 29.4 \\
\hline
\end{tabular}

Assessment of the optimal planting date based on potential yield showed that both the sorghum hybrids and maize performed better when planted early, with a smaller difference between the first and last planting dates for sorghum.

Similar actual yield values were recorded for the different planting dates. The years 2009 and 2013 were considered outliers due to drought stress, which affected the plants in these years. When means were calculated disregarding these years, percent yield declines were $1.3 ; 10.7 ; 13.1 ; 20.3 ; 25.2$ and 32.1 for sorghum group I, $5.0 ; 8.7 ; 16.1 ; 25.3$ and 30.8 for sorghum group II and $6.2 ; 8.8 ; 19.8 ; 32.1 ; 37.3$ and 40.7 for maize.

Based on the results obtained, we believe that the sooner sorghum and maize succession crops are planted (from January onwards or after the summer crop), the better their yields will be, since the results indicate February 20 as the optimal planting date.

In Goiás state, Grossi et al. (2013) observed the smallest sorghum yield reduction for planting dates in January, with losses increasing at later dates. These findings corroborate those of Cardoso, Faria, and Folegatti (2004); Silva et al. (2009); Shioga and Gerage (2010); and Lopez et al. (2017).

\section{Conclusions}

The CERES-Maize and CERES-Sorghum models were efficient at simulating flowering and physiological maturity dates as well as the actual and potential yield in sorghum and maize crops from 2007 to 2015, in Central-West Paraná State.

Leaf area index was satisfactorily simulated for the two sorghum hybrids, but underestimated for the maize hybrid. Both models were limited in simulating the grain filling rate.

Sorghum exhibited greater potential and actual yield stability for the different planting dates, whereas maize yield decreased with later dates.

Sorghum has the same agronomic potential as maize when grown as a succession crop in Central-West Paraná State, depending only on market conditions and farmers' crop management practices.

Farmers could opt to plant sorghum as a succession crop when droughts are forecast for this period since maize is more sensitive to dry weather, whereas sorghum may not be the best alternative when frost is forecast.

\section{References}

Akinseye, F. M., Adam, M., Agele, S. O., Hoffmann, M. P., Traore, P. C. S., \& Whitbread, A. M. (2017). Assessing crop model improvements through comparison of sorghum (Sorghum bicolor L. moench) simulation models: A case study of West African varieties. Field Crops Research, 201(1), 19-31. https://doi.org/10.1016/j.fcr.2016.10.015

Amaral, T. A., Andrade, C. L. T. de, Oliveira, A. C., Silva, D. F., Santana, C. B., Moura, B. F., \& Castro, L. A. (2009). 68/5000 Methodology for establishing the corn sowing period (13 p.). Sete Lagoas: Embrapa Maize and Sorghum. Retrieved from http://ainfo.cnptia.embrapa.br/digital/bitstream/CNPMS-2010/22534/1/ Doc-88.pdf

Bao, Y., Hoogenboom, G., McClendon, R., \& Vellidis, G. (2017). A comparison of the performance of the CSM-CERES-Maize and EPIC models using maize variety trial data. Agricultural Systems, 150(1), 109-119. https://doi.org/10.1016/j.agsy.2016.10.006 
Borghi, E., Crusciol, C. A. C., Nascente, A. S., Sousa, V. V., Martins, P. O., Mateus, G. P., \& Costa, C. (2013). Sorghum grain yield, forage biomass production and revenue as affected by intercropping time. European Journal of Agronomy, 51, 130-139. https://doi.org/10.1016/j.eja.2013.08.006

Cardoso, C. O., Faria, R. T., \& Folegatti, M. V. (2004). Simulation of yield and climate risks for safrinha maize in Londrina-PR, using the model CERES-Maize. Agricultural Engineering, 24(2), 291-300. https://doi.org/ $10.1590 / \mathrm{S} 0100-69162004000200007$

Chimonyo, V. G. P., Modi, A. T., \& Mabhaudhi, T. (2016). Simulating yield and water use of a sorghum-cowpea intercrop using APSIM. Agricultural Water Management, 177, 317-328. https://doi.org/10.1016/j.agwat. 2016.08.021

CONAB (Brazilian Crop Supply Agency). (2018). Brazilian Crop Monitoring: Grains-Crop 2017/2018 (p. 178). Brasília: CONAB. Retrieved from https://www.conab.gov.br/info-agro/safras/graos/boletim-da-safrade-graos

Dallacort, R., Freitas, P. S. L. de, Faria, R. T., Goncalves, A. C. A., Rezende, R., \& Guimarães, R. M. L. (2011). Simulation of bean crop growth, evapotranspiration and yield in Paraná State by the CROPGRO-Dry bean model. Acta Scientiarum. Agronomy, 33(3), 429-436. https://doi.org/10.4025/actasciagron.v33i3.11793

Dokoohaki, H., Gheysari, M., Mousavi, S. F., Zand-Parsa, S., Miguez, F. E., Archontoulis, S. V., \& Hoogenboom, G. (2016). Coupling and testing a new soil water module in DSSAT CERES-Maize model for maize production under semi-arid condition. Agricultural Water Management, 163, 90-99. https://doi.org/ 10.1016/j.agwat.2015.09.002

EMBRAPA. (2013). Sistema brasileiro de classificação dos solos (p. 352). Brasília: EMBRAPA.

Fracasso, A., Trindade, L., \& Amaducci, S. (2016). Drought tolerance strategies highlighted by two Sorghum bicolor races in a dry-down experiment. Journal of Plant Physiology, 190(15), 1-14. https://doi.org/ 10.1016/j.jplph.2015.10.009

Grossi, M. C., Justino, F., Andrade, C. L. T., Santos, E. A., Rodrigues, R. A., \& Costa, L. C. (2013). Modeling the impact of global warming on the sorghum sowing window in distinct climates in Brazil. European Journal of Agronomy, 51, 53-64. https://doi.org/10.1016/j.eja.2013.07.002

Grossi, M. C., Justino, F., Rodrigues, R. A., \& Andrade, C. L. T. (2015). Sensitivity of the sorghum yield to individual changes in climate parameters: modelling based approach. Bragantia, 74(3), 341-349. https://doi.org/10.1590/1678-4499.0411

He, J., Dukes, M. D., Jones, J. W., Graham, W. D., \& Judge, J. (2009). Applying glue for estimating Ceres-Maize genetic and soil parameters for sweet corn production. American Society of Agricultural and Biological Engineers, 52(6), 1907-192. https://doi.org/10.13031/2013.29218

Heinemann, A. B., Andrade, C. L. T., Gomide, R. L., Amorim, A. O., \& Paz, R. L. (2009). Water deficiency patterns for corn crop (normal and second crop) in the state of Goiás and its consequences for genetic improvement. Science and Agrotechnology, 33(4), 1026-1033. Retrieved from https://ainfo.cnptia. embrapa.br/digital/bitstream/item/31793/1/Padroes-deficiencia.pdf

Hoogenboom, G., Jones, J. W., Wilkens, P. W., Porter, C. H., Boote, K. J., Hunt, L. A., ... Koo, J. (2012). Decision Support System for Agrotechnology Transfer (DSSAT) Version 4.5 [CD-ROM]. Honolulu, Hawaii: University of Hawaii.

Houx III, J. H., \& Fritschi, F. B. (2015). Influence of late planting on light interception, radiation use efficiency and biomass production of four sweet sorghum cultivars. Industrial Crops and Products, 76(15), 62-68. https://doi.org/10.1016/j.indcrop.2015.06.036

Jones, J. W., Hoogenboom, G., Porter, C. H., Boote, K. J., Batchelor, W. D., Hunt, L. A., ... Ritchie, J. T. (2003). DSSAT cropping system model. European Journal of Agronomy, 18(3-4), 235-265. https://doi.org/10.1016/ S1161-0301(02)00107-7

Kadiyala, M. D. M., Jones, B. J. W., Mylavarapuc, R. S., Lic, Y. C., \& Reddy, M. D. (2015). Identifying irrigation and nitrogen best management practices for aerobic rice-maize cropping system for semi-arid tropics using CERES-rice and maize models. Agricultural Water Management, 149, 23-32. https://doi.org/ 10.1016/j.agwat.2014.10.019

Liu, H., Yang, J., He, P., Bai, Y., Jin, J., Craig, F. D., ... Hoogenboom, G. (2012). Optimizing parameters of CSM-CERES-Maize model to improve simulation performance of maize growth and nitrogen uptake in 
Northeast China. Journal of Integrative Agriculture, 11(11), 1898-1913. https://doi.org/10.1016/S2095-3119 (12)60196-8

Lopez, J. R., Erickson, J. E., Asseng, S., \& Bobeda, E. L. (2017). Modification of the CERES grain sorghum model to simulate optimum sweet sorghum rooting depth for rainfed production on coarse textured soils in a sub-tropical environment. Agricultural Water Management, 181, 47-55. https://doi.org/10.1016/j.agwat. 2016.11.023

Paiva, C. L., Queiroz, V. A. V., Simeone, M. L. F. Schaffert, R. E., Oliveira, A. C., \& Silva, C. S. (2017). Mineral content of sorghum genotypes and the influence of water stress. Food Chemistry, 214(1), 400-405. https://doi.org/10.1016/j.foodchem.2016.07.067

Pereira, A. M. A. R., Von Pinho, R. G., Paglis, C. M., Pereira, J. L. A. R., \& Altoé, T. F. (2010). Efficiency of the ceres-maize model in the simulation of corn hybrid performance. Ceres Journal, 57(4), 486-493. https://doi.org/10.1590/S0034-737X2010000400008

Piccinni, G., Ko, J., Marek, T., \& Howell, T. (2009). Determination of growth-stage-specific crop coefficients (Kc) of maize and sorghum. Agricultural Water Management, 96(12), 1698-1704. https://doi.org/10.1016/ j.agwat.2009.06.024

Rosa, R. D., Ramos, T. B., \& Pereira, L. S. (2016). The dual Kc approach to assess maize and sweet sorghum transpiration and soil evaporation under saline conditions: Application of the SIMDualKc model. Agricultural Water Management, 177, 77-94. https://doi.org/10.1016/j.agwat.2016.06.028

Shioga, P. S., \& Gerage, A. C. (2010). Influence of planting time on the performance of safrinha corn in the state of Paraná, Brazil. Brazilian Journal of Corn and Sorghum, 9(3), 236-253. https://doi.org/10.18512/ 1980-6477/rbms.v9n3p236-253

Silva, A. G., Barros, A. S., Silva, L. H. C. P., Moraes, E. B., Pires, R., \& Teixeira, I. R. (2009). Evaluation of grain sorghum cultivars in the off-season in southwestern Goiás State. Pesquisa Agropecuária Tropical, 39(2), 168-174. Retrieved from https://www.revistas.ufg.br/pat/article/view/3320/4785

Singh, P., Nedumaran, S., Traore, P. C. S., Boote, K. J., Rattunde, H. F. W., Prasad, P. V. V., ... Bantilan, M. C. S. (2014). Quantifying potential benefits of drought and heat tolerance in rainy season sorghum for adapting to climate change. Agricultural and Forest Meteorology, 185(15), 37-48. https://doi.org/10.1016/j.agrformet. 2013.10.012

Sutka, M. R., Manzur, M. E., Vitali, V. A., Micheletto, S., \& Amodeo, G. (2016). Evidence for the involvement of hydraulic root or shoot adjustments as mechanisms underlying water deficit tolerance in two Sorghum bicolor genotypes. Journal of Plant Physiology, 192(15), 13-0. https://doi.org/10.1016/j.jplph.2016.01.002

Tedeschi, L. O. (2006). Assessment of the adequacy of mathematical models. Agricultural Systems, 89(2-3), 225-247. https://doi.org/10.1016/j.agsy.2005.11.004

Vivan, G. A., Robaina, A. D., Peiter, M. X., Parizi, A. R. C., Barboza, F. S., \& Soares, F. C. (2015). Yield and profitability of soybean, corn and bean crops grown under rainfed conditions. Semina: Ciências Agrárias, 36(5), 2943-2950. https://doi.org/10.5433/1679-0359.2015v36n5p2943-2950

Wagner, M. V., Jadoski, S. O., Maggi, M. F., Saito, L. R., \& Lima, A. S. (2013). Estimated corn yield as a function of water availability in Guarapuava, PR, Brazil. Brazilian Journal of Agricultural and Environmental Engineering, 17(2), 170-179. https://doi.org/10.1590/S1415-43662013000200008

Yi, B., Zhou, Y., Gao, M., Zhang, Z., Han, Y., Yang, G., ... Huang, R. (2014). Effect of drought stress during flowering stage on starch accumulation and starch synthesis enzymes in sorghum grains. Journal of Integrative Agriculture, 13(11), 2399-2406. https://doi.org/10.1016/S2095-3119(13)60694-2

Zegada-Lizarazu, W., Zatta, A. A., \& Monti, A. (2012). Water uptake efficiency and above- and belowground biomass development of sweet sorghum and maize under different water regimes. Plant and Soil, 351(1-2), 47-60. https://doi.org/10.1007/s11104-011-0928-2

\section{Copyrights}

Copyright for this article is retained by the author(s), with first publication rights granted to the journal.

This is an open-access article distributed under the terms and conditions of the Creative Commons Attribution license (http://creativecommons.org/licenses/by/4.0/). 